\title{
Short-term effects by using additional methods in DOBOMED preparation phase for AIS double major patients - pilot study
}

\author{
B Wnuk ${ }^{1 *}$, J Durmala1', J Dzierzega ${ }^{1}$, K Dybula $^{2}$, S Dybula ${ }^{2}$, K Wadolowski $^{2}$ \\ From 8th International Conference on Conservative Management of Spinal Deformities and SOSORT 2011 \\ Annual Meeting \\ Barcelona, Spain. 19-21 May 2011
}

\section{Aim}

The assessment of physiotherapy various models to the clinical examination results - short-term observation during the stationary intensive rehabilitation.

\section{Materials and methods}

Thirty-five girls with AIS double major (mean Cobb's angle $-\mathrm{Th}=27 \mathrm{o} \pm 7,5 ; \mathrm{L}=24 \mathrm{o} \pm 5,6$ ) were divided for two randomized groups. In group A was applied only standard DoboMed [1].

In-group A-plus was applied triple method (DoboMed + OMT Kaltenborn-Evjenth + Dynamic Brace System Meditrac). The derotation manual therapy techniques and Meditrac were used in DoboMed preparation phase. Meditrac was used only in the part of lumbar spine once a day during 30 minutes. The stationary intensive rehabilitation for both groups have been continued during 3 weeks.

Before and after observation have been analyzed: the respiratory system function (spirometry-VC, FEV1, PEF), the strength of respiratory muscles (maximal inspiration and expiratory pressures- MIP,MEP), the trunk morphology and function (kyphosis and range of spine motion by V-plurimeter; the trunk rotation angle-ATR by Bunnell's scoliometer).

\section{Results}

MIP and spine flexion values were increased significantly in both groups during therapy. In the group A-plus was observed more significant changes of parameters. Increasing of PEF, kyphosis, spine extension and lateral flexion values and decreasing of ATR were observed.

${ }^{1}$ Medical University of Silesia, Poland, Katowice, Poland

Full list of author information is available at the end of the article

\section{Conclusions}

In the short time were observed functionally and morphology improvement in-group of patients treated by DoboMed with OMT Kaltenborn-Evjenth and Dynamic Brace System -Meditrac. These additional methods have been used successfully in DoboMed preparation phase for AIS double major patients.

\section{Author details}

${ }^{1}$ Medical University of Silesia, Poland, Katowice, Poland. ${ }^{2}$ University Hospital Silesia Medical Center, Katowice, Poland.

Published: 27 January 2012

\section{Reference}

1. Dobosiewicz K, Durmala J, Kotwicki T: Dobosiewicz method physiotherapy for idiopathic scoliosis. Stud Health Technol Inform 2008, 135:228-36.

doi:10.1186/1748-7161-7-S1-058

Cite this article as: Wnuk et al.: Short-term effects by using additional methods in DOBOMED preparation phase for AIS double major patients pilot study. Scoliosis 2012 7(Suppl 1):O58.

Submit your next manuscript to BioMed Central and take full advantage of:

- Convenient online submission

- Thorough peer review

- No space constraints or color figure charges

- Immediate publication on acceptance

- Inclusion in PubMed, CAS, Scopus and Google Scholar

- Research which is freely available for redistribution

Submit your manuscript at www.biomedcentral.com/submit 